\title{
Tingkat Pengetahuan dan Motivasi lbu Berhubungan dengan Pemberian ASI Eksklusif pada Ibu Bekerja
}

\author{
Tri Utami Listyaningrum ${ }^{1}$, Venny Vidayanti² \\ 1,2Prodi S1 IImu Keperawatan FIKES UNRIYO Jalan Raya Tajem Km 1,5 \\ Maguwoharjo, Depok, Kecamatan Sleman, Daerah Istimewa Yogyakarta \\ Email: vey_chan_88@yahoo.co.id
}

\begin{abstract}
Abstrak
Kendala utama dalam pemberian ASI eksklusif adalah ibu bekerja yang kembali bekerja setelah cuti melahirkan. Selain disebabkan oleh faktor kerja, masih banyak faktor lain yang mempengaruhi pemberian ASI eksklusif. Fenomena yang ditemukan masih ada ibu bekerja yang tidak memberikan ASI eksklusif walaupun mendapat dukungan dari keluarga dan lingkungan kerja. Tujuan penelitian untuk mengetahui hubungan tingkat pengetahuan dan motivasi ibu dengan pemberian ASI eksklusif pada ibu bekerja di PT. Globalindo Intimates Klaten. Penelitian ini merupakan penelitian kuantitatif dengan desain penelitian deskriptif analitik. Populasi adalah seluruh ibu bekerja yang mempunyai bayi 6 bulan - 2 tahun pada bulan Mei 2015. Metode pengambilan sampel menggunakan total sampling berjumlah 37 responden. Hasil analisis menggunakan uji Fisher's Exact Test dengan tingkat kepercayaan 95\% dan $\alpha$ 0,05, diketahui p-value= 0,022 menunjukkan ada hubungan antara pengetahuan ibu tentang ASI eksklusif dengan pemberian ASI eksklusif, sedangkan perhitungan motivasi menunjukkan ada hubungan antara motivasi ibu dengan pemberian ASl eksklusif dengan nilai $p$-value $=0,003$. Kesimpulan ada hubungan antara pengetahuan tentang ASI eksklusif dan motivasi ibu dengan pemberian ASI eksklusif pada ibu bekerja di PT. Globalindo Intimates, Klaten.
\end{abstract}

Kata Kunci: tingkat pengetahuan, motivasi, ASI eksklusif, ibu bekerja

\section{Mother's Level of Knowledge and Mother's Motivation Related with The Exclusive Breastfeeding among Working Mothers}

\begin{abstract}
One of the most problem related to successful exclusive breastfeeding is returning to work after maternity leave. Work and other factors might influence exclusive breastfeeding. It is still found that working mothers do not breastfeed even though their family and their working environment support them. This research is to find out the correlations between mother's level of knowledge, mother's motivation and the exclusive breastfeeding among working mothers in PT. Globalindo Intimates Klaten. This research was a quantitative with descriptive analytic design. A total sampling method was used to collect the data from 37 working mothers having sixmonth-old to two-year-old babies. The data were collected in May 2015. The result indicated that there was a positive correlation between mother's knowledge of exclusive breastfeeding and the practice of exclusive breastfeeding. The Fisher's Exact Test with the confidence level of $95 \%$ and $\alpha 0.05$ data analysis indicate that the $p$-value was 0.022 . The result also indicated that there was a positive correlation between mother's motivation and exclusive breastfeeding with p-value 0.003. Conclussion, there was a positive correlation between mother's knowledge of exclusive breastfeeding and mother's motivation with practice of exclusive breastfeeding among working mothers in PT. Globalindo Intimates Klaten.
\end{abstract}

Keywords: level of knowledge, motivation, exclusive breastfeeding, working mothers

Info Artikel:

Artikel dikirim pada 2 Maret 2016

Artikel diterima pada 23 Maret 2016

DOI : http://dx.doi.org/10.21927/jnki.2016.4(2).55-62 


\section{PENDAHULUAN}

Masalah kesehatan anak di Indonesia dipengaruhi oleh tingginya angka kematian bayi (AKB). Tingginya angka kematian bayi di Indonesia disebabkan oleh kelahiran prematur, infeksi saat kelahiran, rendahnya gizi saat kelahiran, kelainan bawaan (kongenital) serta rendahnya pemberian ASI segera setelah bayi lahir (inisiasi ASI) dan pemberian ASI eksklusif selama 6 bulan pertama kehidupan bayi (1).

Peningkatan program ASI eksklusif merupakan salah satu bentuk usaha pemerintah dalam pencapaian Millenium Development Goals (MDGs) pada tahun 2014. Upaya pemberian ASI eksklusif bermanfaat bagi bayi dalam meningkatkan kekebalan tubuh dan sebagai nutrisi, hal tersebut berperan dalam menekan Angka Kematian Bayi (2). Capaian ASI Eksklusif Kabupaten Klaten pada tahun 2013 sebesar 80,2\% (terdapat 13.142 bayi yang diberi ASI Eksklusif dari jumlah bayi usia 0-6 bulan sejumlah 16.391 bayi (3). Kembali bekerja setelah cuti melahirkan merupakan kendala suksesnya pemberian ASI eksklusif. Selain disebabkan oleh faktor tempat bekerja, masih banyak faktor lain yang mempengaruhi pemberian ASI eksklusif.

Hasil studi pendahuluan yang dilakukan di PT. Globalindo Intimates Klaten kepada 5 karyawati melalui wawancara menunjukkan hasil bahwa hanya satu orang yang memberikan ASI saja sampai usia bayinya 6 bulan, sisanya 4 orang memberikan ASI saja kurang dari 6 bulan dengan memberikan tambahan susu formula dan cairan lain. Seorang karyawati mengatakan tidak memberikan ASI saja karena produksi ASInya sedikit dan tidak mencukupi kebutuhan bayinya. Mereka yang tidak memberikan ASI eksklusif mengaku memberikan ASI dengan kombinasi susu formula dengan alasan bekerja dan fasilitas ruang memerah ASI yang disedikan pabrik kurang memadai. Pabrik menyediakan ruang poliklinik yang juga digunakan sebagai ruang laktasi, ruang laktasi hanya dibatasi tirai, ruang tersebut tidak dikhususkan untuk memerah ASI saja tetapi juga sebagai ruang pemeriksaan kesehatan karyawan. Ketika ibu sedang memerah ASI di ruang tersebut, ibu merasa terburu-buru dan tidak nyaman, ibu juga mengatakan waktu istirahat yang terbatas yaitu 30 menit. Alasan tersebut yang membuat mereka tidak lagi memanfaatkan fasilitas memerah ASI. Kelima karyawati juga mengatakan tidak pernah mendapatkan penyuluhan khusus dari pabrik mengenai ASI eksklusif. Mereka memperoleh informasi hanya dari perawat dan petugas poliklinik, sedangkan sumber informasi lainnya diperoleh dari bidan dan petugas posyandu di dekat tempat tinggal mereka. Kelima karyawati tersebut saat ditanya mengenai ASI eksklusif dapat menjelaskan definisi ASI eksklusif yaitu air susu ibu yang diberikan sejak bayi dilahirkan hingga usia 6 bulan atau ASI yang diberikan pada bayi usia 0-6 bulan tanpa diberikan makanan atau minuman tambahan.

Seorang responden mengatakan mendapat dukungan dari suami, orang tua kandung, mertua dan perusahaan dalam memberikan ASI eksklusif sehingga memberikan ASI eksklusif pada bayinya, sedangkan empat responden lain mengatakan juga mendapat dukungan dari suami, orang tua kandung, mertua dan perusahaan dalam memberikan ASI eksklusif namun karena keterbatasan fasilitas, waktu dan kesibukan bekerja maka ibu tidak lagi memberikan ASI secara eksklusif. Fenomena tersebut menunjukkan bahwa ada faktor motivasi ekstrinsik yang mendukung namun belum ada motivasi intrinsik dari ibu. Tujuan penelitian untuk mengetahui tentang hubungan tingkat pengetahuan dan motivasi ibu dengan pemberian ASI eksklusif pada ibu bekerja di PT. Globalindo Intimates Klaten.

\section{BAHAN DAN METODE}

Jenis penelitian adalah deskriptif analitik dengan rancangan cross sectional. Penelitian ini dilaksanakan pada bulan April-Agustus 2015 di PT. Globalindo Intimates Klaten. Jumlah populasinya adalah 37 orang. Teknik pengambilan sampel dengan total sampling. Kriteria inklusi dalam penelitian ini yaitu ibu yang bekerja di PT. Globalindo Intimates Klaten, bersedia menjadi responden dalam penelitian dan mempunyai anak usia 6 bulan - 2 tahun. Sedangkan kriteria ekslusi dalam penelitian ini yaitu ibu yang dalam masa penelitian dalam keadaan sakit dan ibu yang dalam masa penelitian menyatakan keluar atau berhenti bekerja di PT. Globalindo Intimates Klaten. Teknik pengumpulan data yang digunakan dalam penelitian ini dengan membagikan tiga buah kuesioner, yaitu kuesioner untuk menilai tingkat pengetahuan, motivasi ibu dan pemberian ASI eksklusif. Kuesioner pengetahuan dan pemberian ASI eksklusif dibuat sendiri oleh peneliti terdiri dari 17 pernyataan tertutup berupa pernyataan favourable dan unfavourable. Instrumen 
untuk mengukur pemberian ASI eksklusif pada ibu bekerja, jumlah pertanyaan 5 soal dengan pilihan jawaban ya dan tidak. Uji validitas dalam penelitian ini menggunakan uji expert judgment dengan meminta pendapat para ahli di bidang Keperawatan Maternitas (4). Kuesioner motivasi diadopsi dari penelitian Suryaningsih, terdiri dari 17 pernyataan dengan hasil uji reliabilitas 0,972 dan item pernyataan sudah dinyatakan valid (5). Analisis univariat untuk mengetahui karakteristik responden (umur, pendidikan dan paritas), pengetahuan tentang ASI eksklusif, motivasi ibu dan pemberian ASI eksklusif. Analisis bivariat menggunakan uji statistik fisher exact.

\section{HASIL DAN BAHASAN}

\section{Karakteristik Responden}

Distribusi frekuensi karakteristik ibu bekerja di PT. Globalindo Intimates Klaten dibagi berdasarkan usia ibu, pendidikan, dan paritas yang disajikan dalam Tabel 1.

Tabel 1. Distribusi Frekuensi Karakteristik Ibu Bekerja di PT. Globalindo Intimates Klaten, pada Bulan Mei $2015(n=37)$

\begin{tabular}{lcc}
\hline \multicolumn{1}{c}{ Karakteristik } & $\mathbf{n}$ & $\mathbf{\%}$ \\
\hline Usia Ibu & 3 & \\
$\quad<20$ tahun & 32 & 86,4 \\
$20-35$ tahun & 3 & 8,1 \\
$>35$ tahun & & \\
Pendidikan Ibu & 10 & 27,0 \\
$\quad$ Dasar & 25 & 67,6 \\
$\quad$ Menengah & 2 & 5,4 \\
$\quad$ Tinggi & & \\
Paritas & 14 & 37,8 \\
$\quad$ Primipara & 23 & 62,2 \\
$\quad$ Multipara & 37 & 100,0 \\
Total
\end{tabular}

Sumber: Data Primer Tahun 2015

Berdasarkan Tabel 1 dapat diketahui bahwa karakteristik responden berdasarkan usia, mayoritas ibu menyusui termasuk dalam kategori usia 20-35 tahun sebanyak 32 orang $(86,5 \%)$. Karakteristik responden berdasarkan pendidikan, mayoritas responden memiliki tingkat pendidikan menengah sebanyak 25 orang $(67,6 \%)$. Karakteristik responden berdasarkan paritas, mayoritas responden termasuk kategori multipara sebanyak 23 orang $(62,2 \%)$. Hasil penelitian sejalan dengan penelitian Maulida yang menyatakan bahwa sebagian besar responden adalah yang berusia 20-35 tahun, yaitu sebanyak 35 responden $(72,9 \%)$ dan sebagian besar memiliki pendidikan pada kategori menengah yaitu sebanyak 25 responden $(52,1 \%)(6)$.

Hasil analisis menunjukkan bahwa dari segi umur mayoritas responden di PT.Globalindo Intimates Klaten berusia reproduksi sehat. Umur ibu sangat menentukan kesehatan maternal karena berkaitan dengan kondisi kehamilan, nifas, serta cara mengasuh juga menyusui bayinya. lbu yang berumur kurang dari 20 tahun masih belum matang dan belum siap secara jasmani dan sosial dalam menghadapi kehamilan dan persalinan. Ibu yang berumur 20-35 tahun termasuk dalam masa reproduksi sehat, di mana masa ini pertumbuhan fungsi tubuh berada pada tingkat yang optimal ditandai dengan rangsangaan kelenjar susu dalam memproduksi ASI oleh hormon progesteron dan estrogen (7). Menurut Arini, pada umur 35 tahun lebih, ibu melahirkan termasuk beresiko karena erat kaitannya dengan anemia gizi yang dapat mempengaruhi produksi ASI. Ibu akan lebih banyak menemukan kendala seperti produksi ASI berkurang dan mudah lelah (8).

Karakteristik responden berdasarkan pendidikan hasil penelitian di PT. Globalindo Intimates, Klaten menunjukkan bahwa rata-rata pendidikan ibu adalah pendidikan menengah. Semakin tinggi pendidikan seseorang maka semakin mudah pula mereka menerima informasi, dan pada akhirnya makin banyak pula pengetahuan yang dimilikinya. Sebaliknya, jika seseorang tingkat pendidikannya rendah, akan menghambat perkembangan sikap seseorang terhadap penerimaan informasi dan nilainilai yang baru diperkenalkan. Tingkat pendidikan ibu yang tinggi akan semakin memudahkan ibu dalam menyerap informasi tentang pemberian ASI eksklusif (9).

Karakteristik responden berdasarkan paritas dapat diketahui bahwa sebagian besar ibu dengan paritas multipara. Ibu multipara menunjukkan angka yang lebih tinggi dalam memberikan ASI eksklusif dibanding ibu primipara, dimana sebagian besar responden memiliki pengalaman menyusui sebelumnya, pengalaman ini akan memperbesar kemungkinan ibu untuk memberikan ASI eksklusif. Ibu yang memiliki pengalaman akan lebih mampu menghadapi kendala yang dirasakan karena sebelumnya sudah pernah menemui kendala yang sama (10). 
Tingkat Pengetahuan Ibu Bekerja tentang ASI Eksklusif di PT. Gobalindo Intimates Klaten, pada Bulan Mei 2015

Distribusi frekuensi tingkat pengetahuan ibu bekerja tentang ASI eksklusif di PT. Globalindo Intimates Klaten disajikan dalam Tabel 2.

Tabel 2. Distribusi Frekuensi Tingkat Pengetahuan Ibu Bekerja Tentang ASI Eksklusif di PT. Gobalindo Intimates Klaten, pada Bulan Mei $2015(n=37)$

\begin{tabular}{lcc}
\hline Tingkat Pengetahuan & $\mathbf{n}$ & \% \\
\hline Baik & 19 & 51,4 \\
Kurang & 18 & 48,6 \\
Total & 37 & 100 \\
\hline
\end{tabular}

Sumber: Data Primer Tahun 2015

Berdasarkan Tabel 2 dapat diketahui bahwa tingkat pengetahuan ibu tentang ASI eksklusif lebih banyak responden termasuk dalam kategori pengetahuan baik sebanyak 19 orang $(51,4 \%)$. Data tersebut menunjukkan bahwa pengetahuan tentang ASI eksklusif lebih banyak responden berada pada kategori baik. Hal ini sejalan dengan hasil penelitian Robiwala yang menyatakan bahwa tingkat pengetahuan ibu tentang ASI eksklusif sebagian besar dalam kategori baik sebesar 87,8\% (11).

Hasil penelitian masih terdapat responden dengan kategori pengetahuan kurang, kemungkinan hal tersebut dapat terjadi karena responden mengetahui definisi ASI eksklusif namun belum memahami komposisi dan manfaat ASI eksklusif terlihat pada jawaban kuesioner rata-rata responden menjawab salah pada indikator komposisi dan manfaat ASI eksklusif. Hasil penelitian ini didukung oleh Sari, yang menunjukkan bahwa pengetahuan responden sebagian besar adalah dalam kategori kurang yaitu sebanyak $45,7 \%$. Pengetahuan yang kurang dikarenakan ibu yang menjadi responden kurang memahami arti pentingnya ASI eksklusif bagi bayi. Pekerjaan ibu yang sebagian besar sebagai pekerja swasta yaitu sebagai karyawan pabrik dengan tingkat pendidikan yang rendah menyebabkan informasi mengenai ASI eksklusif tidak dapat dipahami dengan baik. Pengetahuan kurang dalam penelitian ini juga dapat dikarenakan budaya masyarakat yang menganut cara lama dalam mengasuh bayi. Orang tua terdahulu mempunyai anggapan bahwa jika anak menangis adalah pertanda bahwa anak lapar, sehingga ASI saja dianggap tidak cukup dan harus diberikan makanan tambahan lain seperti pisang atau makanan-makanan lunak lain yang dapat membuat bayi merasa kenyang dan akhirnya tenang (12).

Motivasi Ibu dalam Pemberian ASI Eksklusif di PT. Gobalindo Intimates Klaten, pada Bulan Mei 2015

Distribusi frekuensi motivasi ibu bekerja dalam pemberian ASI eksklusif di PT. Globalindo Intimates Klaten disajikan dalam Tabel 3.

Tabel 3. Distribusi Frekuensi Motivasi Ibu dalam Pemberian ASI Eksklusif di PT. Globalindo Intimates Klaten, pada Bulan Mei $2015(n=37)$

\begin{tabular}{lcc}
\hline \multicolumn{1}{r}{ Motivasi } & $\mathbf{n}$ & \% \\
\hline Tinggi & 19 & 51,4 \\
Rendah & 18 & 48,6 \\
Total & 37 & 100 \\
\hline
\end{tabular}

Sumber: Data Primer Tahun 2015

Berdasarkan Tabel 3 dapat diketahui bahwa motivasi ibu dalam pemberian ASI eksklusif yang terbanyak responden termasuk dalam kategori motivasi tinggi sebanyak 19 orang $(51,4 \%)$ dan motivasi rendah sebanyak 18 orang $(48,6 \%)$. Data tersebut menunjukkan bahwa motivasi ibu dalam pemberian ASI eksklusif lebih banyak responden berada pada kategori motivasi tinggi, meskipun banyak responden dalam kategori motivasi tinggi namun masih terdapat responden dengan motivasi rendah. Hal tersebut terjadi karena masih rendahnya tingkat pendidikan ibu.

Penelitian ini didukung oleh penelitian yang dilakukan oleh $\mathrm{Nia}$, didapatkan hasil sebagian besar 26 responden atau $(68,4 \%)$ ibu bermotivasi rendah dalam pemberian ASI eksklusif (13). Sejalan dengan penelitian yang dilakukan oleh Indah dan Dian dari 28 responden, sebanyak $53,6 \%$ responden berpendidikan dasar. Motivasi seseorang dipengaruhi oleh tingkat pendidikan, seseorang yang mempunyai tingkat pendidikan rendah otomatis pengetahuan yang dimiliki juga sedikit, maka maka informasi yang diperoleh akan lebih sulit diterima dengan baik sehingga motivasi yang ada dari dalam diri ibu juga rendah (14).

Hasil penelitian tidak sejalan dengan hasil penelitian Maulida, yang menyatakan bahwa sebagian besar responden memiliki motivasi dalam memberikan ASI eksklusif pada bayi usia 0-6 bulan berada pada kategori sedang yaitu sebanyak 21 responden $(43,7 \%)$, dan sebagian kecil responden memiliki motivasi tinggi yaitu sebanyak 13 responden $(27,1 \%)(6)$. 
Pemberian ASI Eksklusif pada Ibu Bekerja di PT. Gobalindo Intimates Klaten, pada Bulan Mei 2015

Distribusi frekuensi pemberian ASI eksklusif di PT. Globalindo Intimates Klaten disajikan dalam Tabel 4.

Tabel 4. Distribusi Frekuensi Pemberian ASI Eksklusif pada Ibu Bekerja di PT. Gobalindo Intimates Klaten, pada Bulan Mei $2015(n=37)$

\begin{tabular}{lcc}
\hline \multicolumn{1}{c}{ Pemberian ASI } & $\mathbf{n}$ & \% \\
\hline Eksklusif & 18 & 48,6 \\
Tidak Eksklusif & 19 & 51,4 \\
Total & 37 & 100 \\
\hline
\end{tabular}

Sumber: Data Primer Tahun 2015

Berdasarkan Tabel 4 dapat diketahui bahwa pemberian ASI eksklusif pada ibu bekerja lebih banyak responden termasuk dalam kategori ASI tidak eksklusif sebanyak 19 orang $(51,4 \%)$ dan sebanyak 18 orang $(48,6 \%)$ termasuk dalam kategori ASI eksklusif.

Hasil penelitian ini didukung oleh penelitian yang dilakukan oleh Wulan, yang menunjukan bahwa sebagian besar responden tidak memberikan ASI eksklusif, yaitu sejumlah 49 responden $(76,6 \%)$ (15). Hal ini dikarenakan ibu kurang memahami manfaat pemberian ASI eksklusif pada bayinya. Padahal menurut Maryunani, keuntungan ASI Eksklusif bagi bayi yaitu mendapatkan zat antibody alami, mengurangi resiko alergi, sterilisai ASI terjamin dan ASI lebih mudah dicerna dan diserap oleh usus bayi. Ibu yang bekerja cenderung akan memberikan susu formula kepada bayinya saat meninggalkan bayinya (16).

Berdasarkan hasil penelitian Sari, diketahui bahwa sebagian besar ibu tidak memberikan ASI secara eksklusif kepada bayinya yaitu sebanyak $85,7 \%$. Banyaknya ibu yang tidak memberikan ASI secara eksklusif kepada bayinya disebabkan oleh berbagai macam faktor. Ibu yang menjadi responden penelitian ini semuanya bekerja di luar rumah.
Aktivitas bekerja di luar rumah inilah yang menjadi faktor penentu rendahnya pemberian ASI eksklusif kepada bayinya hingga usia 6 bulan. Pada ibu bekerja pemberian ASI eksklusif sering kali mengalami hambatan karena jam kerja yang sangat terbatas dan kesibukan dalam melaksanakan pekerjaan (12).

Menurut Haryani, pada ibu bekerja yang tidak memberikan ASI eksklusif pada bayinya, ditemukan beberapa alasan, antara lain: adanya rasa malas dari ibu, karena tuntutan beban kerja yang tinggi, waktu cuti yang sedikit, sarana prasarana yang kurang dan adannya tuntutan kebutuhan ekonomi keluarga. Sehingga para ibu tersebut memilih untuk tidak memberikan ASI eksklusif pada bayinya, sebagian besar memberikan ASI hanya 1 bulan saja dan selanjutnya pemberian ASI dicampur atau diganti dengan susu formula (17).

\section{Hubungan antara Tingkat Pengetahuan dengan Pemberian ASI Eksklusif}

Berdasarkan Tabel 5 dapat diketahui bahwa pada kategori responden dengan pengetahuan baik sebagian besar memberikan ASI eksklusif sebanyak 13 orang $(35,1 \%)$ sedangkan responden dengan kategori pengetahuan kurang sebagian besar tidak memberikan ASI eksklusif sebanyak 13 orang $(35,1 \%)$. Hasil analisis dapat diketahui bahwa $p$-value $=0,022(<0,05)$ yang artinya ada hubungan antara pengetahuan tentang ASI eksklusif dengan pemberian ASI eksklusif pada ibu bekerja di PT. Globalindo Intimates, Klaten.

Penelitian ini sejalan dengan penelitian yang dilakukan oleh Diana, yang menyatakan bahwa fenomena kurangnya pemberian ASI eksklusif disebabkan oleh pengetahuan ibu yang kurang memadai tentang ASI eksklusif, beredarnya mitos yang kurang baik, serta kesibukan ibu bekerja dan singkatnya cuti melahirkan merupakan alasan yang diungkapkan oleh ibu yang tidak menyusui secara eksklusif (18). Hal ini kemungkinan disebabkan

Tabel 5. Hubungan antara Tingkat Pengetahuan dengan Pemberian ASI Eksklusif di PT. Gobalindo Intimates Klaten, pada Bulan Mei $2015(n=37)$

\begin{tabular}{lccccc}
\hline $\begin{array}{c}\text { Pengetahuan } \\
\text { tentang ASI } \\
\text { Eksklusif }\end{array}$ & Eksklusif & $\%$ & $\begin{array}{c}\text { Tidak } \\
\text { Eksklusif }\end{array}$ & $\%$ & $\begin{array}{c}\text { Fisher } \\
\text { Exact Test }\end{array}$ \\
\cline { 2 - 5 } & 13 & 35,1 & 6 & 16,2 & \\
\hline Baik & 5 & 13,5 & 13 & 35,1 & 0,022 \\
Kurang & 18 & & 19 & & \\
Jumlah & & &
\end{tabular}

Sumber: Data Primer Tahun 2015 
karena faktor pekerjaan dimana lingkungan kerja adalah salah satu faktor yang mempengaruhi pengetahuan (9).

Fenomena yang didapatkan di PT. Globalindo Intimates Klaten bahwa perusahaan sangat mendukung pemberian ASI eksklusif. Adanya fasilitas poliklinik dengan ruang laktasi dengan satu dokter dan perawat dapat memudahkan ibu bekerja untuk mendapatkan informasi, bila ibu kurang memahami tentang ASI eksklusif maka dapat bertanya pada petugas kesehatan di poliklinik. Informasi tersebut yang akan menambah pengetahuan ibu bekerja.

Laurance Green dalam Notoadmodjo, mengatakan bahwa perilaku seseorang terbentuk dari 3 faktor, salah satunya adalah faktor predisposisi yang terwujud dalam pengetahuan. Pengetahuan atau kognitif merupakan domain yang sangat penting dalam membentuk tindakan seseorang. Pengetahuan dipengaruhi oleh 3 faktor, satu di antaranya adalah pendidikan (19). Makin tinggi pendidikan seseorang makin mudah seseorang untuk menerima informasi sehingga makin banyak pula pengetahuan yang dimiliki dan sebaliknya makin rendah pendidikan seseorang maka akan menghambat perkembangan sikap seseorang terhadap nilai-nilai yang baru diperkenalkan. Tingkat pendidikan ibu yang rendah mengakibatkan kurangnya pengetahuan ibu dalam menghadapi masalah, terutama dalam pemberian ASI eksklusif. Pengetahuan ini diperoleh baik secara formal maupun informal. Sedangkan ibu-ibu yang mempunyai tingkat pendidikan yang lebih tinggi, umumnya terbuka menerima perubahan atau halhal guna pemeliharaan kesehatannya. Pendidikan juga akan membuat seseorang terdorong untuk ingin tahu mencari pengalaman sehingga informasi yang diterima akan menjadi pengetahuan.

Umur juga mempengaruhi pengetahuan, berdasarkan hasil penelitian yang dilakukan Arini bahwa semakin meningkat umur maka persentase berpengetahuan semakin baik karena disebabkan oleh akses informasi, wawasan, dan mobilitas yang masih rendah. Arini juga berpendapat bahwa semakin meningkatnya umur dan tingkat kematangan maka kekuatan seseorang dalam berpikir dan bekerja juga akan lebih matang (8).

Pengetahuan bukanlah satu-satunya faktor yang mempengaruhi pemberian ASI eksklusif hal ini dapat dilihat dari hasil analisis tabel silang dimana masih terdapat $16,2 \%$ responden dengan pengetahuan baik namun tidak memberikan ASI eksklusif, hal ini diasumsikan adanya faktor lain yang mempengaruhi perilaku ibu dalam pemberian ASI eksklusif seperti faktor kejiwaan ibu, faktor dari bayi sendiri, kelainan payudara, lingkungan dan kebudayaan.

\section{Hubungan antara Motivasi lbu dengan Pemberian ASI Eksklusif}

Hubungan antara motivasi ibu bekerja dengan pemberian ASI eksklusif di PT. Gobalindo Intimates Klaten disajikan dalam Tabel 6.

Tabel 6. Hubungan antara Motivasi lbu dengan Pemberian ASI Eksklusif di PT. Globalindo Intimates Klaten, pada Bulan Mei 2015 ( $n=37)$

\begin{tabular}{lccccc}
\hline \multirow{4}{*}{ Motivasi } & \multicolumn{4}{c}{ Pemberian ASI } & Fisher \\
\cline { 2 - 5 } & Eksklusif & $\%$ & $\begin{array}{c}\text { Tidak } \\
\text { Eksklusif }\end{array}$ & $\%$ & $\begin{array}{c}\text { Exact } \\
\text { Test }\end{array}$ \\
\hline Tinggi & 14 & 37,8 & 5 & 13,5 & \\
Rendah & 4 & 10,8 & 14 & 37,8 & 0,003 \\
Jumlah & 18 & & 19 & & \\
\hline
\end{tabular}

Sumber: Data Primer Tahun 2015

Berdasarkan Tabel 6 dapat diketahui bahwa pada kategori responden dengan motivasi tinggi sebagian besar memberikan ASI eksklusif sebanyak 14 orang $(37,8 \%)$, sedangkan responden dengan kategori motivasi rendah sebagian besar memberikan ASI tidak eksklusif sebanyak 14 orang (37,8\%). Hasil analisis diperoleh $p$-value $=0,003(<0,05)$. Hasil perhitungan menunjukkan bahwa ada hubungan antara motivasi ibu dengan pemberian ASI eksklusif pada ibu bekerja di PT. Globalindo Intimates, Klaten.

Penelitian ini sejalan dengan penelitian yang dilakukan oleh Indrayani, bahwa ada hubungan dukungan suami dengan motivasi ibu nifas dalam memberikan ASI eksklusif di puskesmas Tegalrejo Yogyakarta dengan nilai $p$-value $=0,002$ (20). Penelitian ini menunjukkan bahwa motivasi berhubungan dengan pemberian ASI eksklusif dimana responden dengan motivasi tinggi akan memberikan ASI eksklusif.

Penelitian yang telah dilakukan di PT. Globalindo Intimates Klaten masih menunjukkan adanya responden dengan motivasi tinggi namun tidak memberikan ASI eksklusif yaitu sebesar (13,5\%), kemungkinan hal tersebut karena mereka terlalu sibuk dan tidak bisa meninggalkan pekerjaan mereka dalam waktu yang lama, sehingga mereka membiasakan bayi mereka minum dari botol dengan susu formula atau makanan tambahan sejak dini. Hasil penelitian 
juga menunjukkan masih ada responden dengan motivasi rendah hal tersebut kemungkinan karena belum adanya motivasi intrinsik yang kuat pada responden di mana motivasi intrinsik datang dari hati sanubari umumnya karena kesadaran (21).

Hasil analisis regresi Dianning, menunjukkan bahwa faktor yang paling berpengaruh terhadap pemberian ASI eksklusif adalah faktor status pekerjaan (22). Responden yang tidak bekerja berpeluang untuk memberikan ASI eksklusif kepada bayinya 4 kali dibanding responden yang bekerja, setelah dikontrol oleh faktor usia, urutan kelahiran bayi, dukungan petugas kesehatan dan sosial budaya. Ketika wanita sudah memutuskan untuk bekerja, wanita harus siap menjalankan peran ganda yang disandangnya. Peran ganda seperti ini yang menjadi permasalahan. Dampak ibu bekerja pada anak sangat luas, dapat menyangkut kesehatan, keamanan, kebahagiaan, pendidikan anak dan sebagainya. Hal ini dikarenakan saat ibu bekerja di luar rumah anak dititipkan pada saudara, atau nenek ataupun pembantu. Dengan demikian, saat ibu bekerja anak sangat tergantung pada siapa tokoh yang menggantikan ibu ketika meninggalkan rumah. Pulang dari kerja, kondisi fisik dan mental yang lelah setelah bekerja sepanjang hari telah menghambat kelancaran produksi ASI. Hal ini mengurungkan niat ibu bekerja untuk memberikan ASI eksklusif. Pada ibu yang bekerja, singkatnya masa cuti hamil atau melahirkan mengakibatkan sebelum masa pemberian ASI eksklusif berakhir sudah harus kembali bekerja. Hal ini mengganggu upaya pemberian ASI eksklusif. ASI eksklusif harus dijalani selama 6 bulan tanpa intervensi makanan dan minuman lain, sedangkan cuti hamil dan melahirkan hanya diberikan selama 3 bulan (22).

Menurut penelitian Angrayni, salah satu faktor yang dapat mempengaruhi suksesnya pemberian ASI eksklusif adalah adanya dukungan keluarga yaitu suami. Keluarga adalah orang terdekat dari ibu yang dapat berhubungan langsung secara emosional. Adanya dukungan dari keluarga dapat berupa motivasi bagi ibu untuk terus menyusui seperti membantu pekerjaan rumah selagi ibu menyusui dan membantu menyediakan makanan bergizi bagi ibu yang dapat mempengaruhi psikologis ibu sehingga produksi ASI lebih lancar. Adapun dukungan keluarga yang diperoleh ibu saat memberikan ASI eksklusif seperti keluarga menganjurkan ibu untuk menyusui dibanding memberikan susu formula, dan tidak pernah disarankan dalam memberi makanan tambahan pada usia bayi 6 bulan pertama. Dukungan keluarga yang rendah akan mengurangi motivasi ibu untuk memberikan ASI secara eksklusif pada bayinya (23).

\section{SIMPULAN DAN SARAN}

Karakteristik responden mayoritas responden berusia 20-35 tahun, mayoritas responden termasuk dalam kategori pendidikan menengah, sebagian besar ibu termasuk kategori paritas multipara. Tingkat pengetahuan ibu tentang ASI eksklusif lebih banyak responden berpengetahuan baik dibanding responden dengan pengetahuan kurang. Motivasi ibu dalam pemberian ASI eksklusif dibagi dalam dua kategori yaitu responden dengan motivasi tinggi lebih banyak dibanding responden dengan motivasi rendah. Pemberian ASI eksklusif pada ibu bekerja di PT. Globalindo Intimates Klaten sebagian besar responden termasuk dalam kategori ASI tidak eksklusif, lebih banyak dibanding responden dalam kategori ASI eksklusif, Ada hubungan tingkat pengetahuan dan motivasi ibu dengan pemberian ASI eksklusif pada ibu bekerja di PT. Globalindo Intimates Klaten.

Bagi ibu bekerja di PT. Globalindo Intimates Klaten hendaknya dapat memanfaatkan kebijakan dan fasilitas laktasi di perusahaan secara maksimal untuk meningkatkan pemberian ASI eksklusif. Bagi peneliti selanjutnya hendaknya dapat melakukan penelitian yang lebih mendalam tentang faktor-faktor lain yang mempengaruhi pemberian ASI eksklusif.

\section{RUJUKAN}

1. BPS, BKKBN, Kementrian Kesehatan. Survey Demografi dan Kesehatan Indonesia (SDKI) 2012. Jakarta; 2012.

2. Dinkes Provinsi Jawa Tengah. Profil Kesehatan Provinsi Jawa Tengah Tahun 2013. Jawa Tengah; 2013.

3. Dinkes Kabupaten Klaten. Profil Kesehatan Kabupaten Klaten Tahun 2013. Klaten; 2014.

4. Sugiyono. Statistika untuk Penelitian. Bandung: Alfabeta; 2015.

5. Suryaningsih. Pengaruh Demonstrasi ASI dan Pendampingan Menyusui Terhadap Motivasi dan Kemampuan Ibu dalam Pemberian ASI. Universitas Indonesia; 2012.

6. Maulida H, Afifah E, Sari DP. Tingkat Ekonomi 
dan Motivasi Ibu dalam Pemberian ASI Eksklusif pada Bayi Usia 0-6 Bulan Di Bidan Praktek Swasta (BPS) Ummi Latifah Argomulyo, Sedayu Yogyakarta. J Ners dan Kebidanan Indones. 2015;3(2):117-23.

7. Rahmawati A, Burhanuddin B, Abdul S. Hubungan antara Karakteristik Ibu, Petugas Kesehatan, dan dukungan Keluarga dengan Pemberian ASI Eksklusif di Wilayah Kerja Puskesmas Bonto Cani Kabupaten Bone. Makasar; 2013.

8. Arini. Mengapa Seorang Ibu Menyusui? Yogyakarta: Flash Book; 2012.

9. Mubarak WI. Promosi Kesehatan. Yogyakarta: Graha IImu; 2007.

10. Lestari A, Mira T, Restuning W. Motivasi Ibu Bekerja dalam Memberikan Asi Eksklusif di PT. Dewhirst Men's Wear Indonesia. Bandung; 2012.

11. Robiwala ME, Ciptorini D, Handini KD. Hubungan Tingkat Pengetahuan Ibu Tentang Asi Eksklusif Dengan Pemberian Asi Saja Di Wilayah Kerja Puskesmas Kokap 1 Kabupaten Kulon Progo Propinsi Yogyakarta. J Med Respati. 2013;8(1):1-18.

12. Sari, Budi, Wening. Hubungan Tingkat Pengetahuan Ibu Bekerja dengan Pemberian ASI Eksklusif di Desa Sumberejo Kecamatan Mranggen Kabupaten Demak. Semarang; 2011.

13. Nia AH. Motivasi pemberian asi eksklusif pada primipara Di Wilayah Kerja Puskesmas Jetis, Ponorogo [Internet]. 2013. Available from: http:// onesearch.id/Record/IOS2857-oai:eprints.umpo. ac.id:326

14. Indah, Dian. Hubungan antara Motivasi dengan Pemberian ASI Eksklusif di Desa Balun Kecamatan Turi Kabupaten Lamongan. 2008.
15. Wulan AS. Faktor-faktor yang Berhubungan dengan Pemberian ASI Eksklusif di Desa Bawen Kecamatan Bawen Kabupaten Semarang. Ungaran; 2013.

16. Maryunani, Nurhayati. Asuhan Kegawatdaruratan dan Penyakit pada Neonatus. Jakarta: Trans Info Medika; 2012.

17. Haryani. Alasan Tidak Diberikan ASI Eksklusif Oleh Ibu Bekerja Di Kota Mataram Nusa Tenggara Barat. Universitas Udayana; 2014.

18. Diana. Faktor yang Berperan dalam Kegagalan Praktik Pemberian Asi Eksklusif Studi Kualitatif di Kecamatan Tembalang, Kota Semarang. Universitas Diponegoro; 2007.

19. Notoatmodjo S. Promosi Kesehatan dan IImu Perilaku. Jakarta: PT. Rineka Cipta; 2007.

20. Indrayani, Tutik, Bernadeta. Hubungan Dukungan Suami dengan Motivasi lbu Nifas dalam Memberikan ASI Eksklusif di Puskesmas Tegalrejo Yogyakarta. Yogyakarta; 2011.

21. Sardiman. Interaksi dan Motivasi Belajar-Mengajar. Jakarta: PT. Raja Grafindo Persada; 2011.

22. Dianning $M$, Rahmawati. Faktor-faktor yang Mempengaruhi Pemberian ASI Eksklusif pada Ibu Menyusui di Kelurahan Pedalangan Kecamatan Banyumanik Kota Semarang. J Kesmadaska. 2010;1(1):8-17.

23. Angrayni, Aminuddin, Hendrayati. Gambaran Pengetahuan, Pekerjaan dan Dukungan Keluarga Terhadap Pemberian ASI Eksklusif Pada A Bayi Umur 6-11 Bulan ULAN Di I Puskesmas Antang PERUMNAS Kota Makassar. 2013. 